\title{
Impact of violation of construction and environmental norms of correctional institutions on the organization of the imprisonment regime
}

\author{
Ivan Karavaev ${ }^{1, *}$, Vladimir Kotlyar $^{1}$, Andrey Antipov ${ }^{1}$, and Ekaterina Ilyinova ${ }^{1}$ \\ ${ }^{1}$ Academy of the Federal penitentiary service of Russian Federation, 1 Sennaya str., Ryazan, 390000, \\ Russian Federation
}

\begin{abstract}
Imprisonment is the most commonly used criminal punishment in the world. In all countries, there are specialized institutions for the maintenance of those sentenced to this punishment. In Russia they are called correctional institutions. By isolating persons who have committed crimes from the outside world, these institutions perform several tasks at once, ensuring: 1) constant monitoring of convicts; 2) access control; 3) control over the movement of convicts; 4) checking their presence; 5) carrying out activities aimed at detecting prohibited items. All these tasks are aimed at achieving a global goal - maintaining the established regime for execution of sentences in form of imprisonment. The article deals with regulation of design, construction and equipment of correctional institutions by Russian legislation. The authors analyze the norms in force in Russia in this area, highlight strengths and weaknesses, and determine the degree of influence of possible violations in design, construction and equipment on the regime of punishment execution. The actual double subordination is established in solving the current problem. On the one hand, the department executing preliminary conclusion, on the other, the department organizing and controlling process of designing and building institutions executing a preventive measure. Such inconsistency creates problems in practical application of provisions of existing norms, leads to errors and, as a result, to inadequate isolation of convicts from the outside world.
\end{abstract}

\section{Introduction}

The Federal Penitentiary Service of Russia (hereinafter - FPS) operates a whole complex of different types of correctional institutions, depending on the categories of convicts. Separately allocated are prisons, colonies for prisoners sentenced to life imprisonment and educational colonies intended for keeping minors sentenced to imprisonment. The number of correctional institutions (colonies of all types, colonies of a

\footnotetext{
${ }^{*}$ Corresponding author: karavaev-i-v@yandex.ru
} 
special regime for those sentenced to life imprisonment, prisons and educational colonies for minors) is given in Fig. 1 [4].

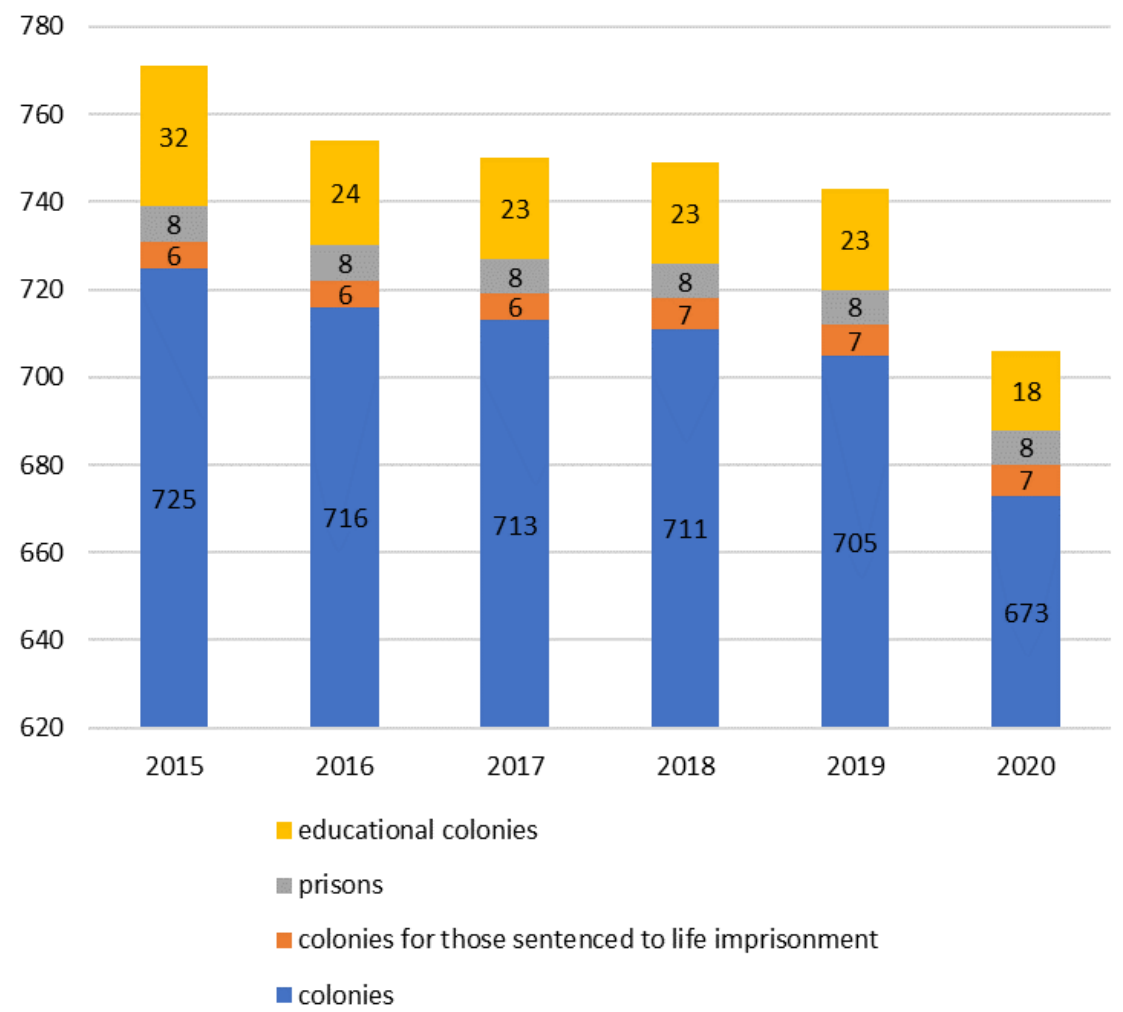

Fig. 1. The number of correctional institutions in Russia.

There is currently a federal target program "Development of penal system (20172025)", which states the need to bring conditions for serving sentences in line with legislation of Russian Federation. It is necessary to additionally create at least 1.8 thousand places in correctional colonies of a strict regime, 1.8 thousand places in correctional colonies of a special regime, 0.7 thousand places in correctional colonies of a special regime for persons sentenced to life imprisonment, 0.65 thousand places for convicted women, 13 orphanages, 0.3 thousand places for convicted men in general regime colonies, as well as reconstruct and build dormitories for 2.485 thousand places to replace emergency and unusable ones, build and reconstruct 19 buildings with rooms with strict conditions for holding convicts for 1660 places, 32 buildings for cell-type rooms, single cell-type rooms, punishment cells for 2,087 thousand places and 503 auxiliary facilities (rooms for long visits, boiler rooms, sanitary inspection baths, medical parts, engineering networks, treatment facilities, security structures, engineering means of protection and supervision, etc.) in correctional institutions. The total funding for these events from 2021 to 2025 is shown in Table 1. 
Table 1. Amounts of financing of measures for construction and reconstruction of facilities and purchase of equipment for the needs of production complex of penitentiary system in accordance with the federal target program "Development of penitentiary system (2017 - 2025)" (million rubles, taking into account the price forecast).

\begin{tabular}{|c|c|c|c|c|c|c|}
\hline Indicator & 2021 & 2022 & 2023 & 2024 & 2025 & $2017-2025$ total \\
\hline $\begin{array}{l}\text { The first option } \\
\text { total: }\end{array}$ & 14152.4351 & 14150.7431 & 13488.6999 & 12469.1094 & 8750.444 & 96500 \\
\hline \multicolumn{7}{|l|}{ including: } \\
\hline $\begin{array}{l}\text { government capital } \\
\text { investment }\end{array}$ & 13652.4351 & 13650.7431 & 12988.6999 & 11969.1094 & 8250.444 & 92000 \\
\hline other needs & 500 & 500 & 500 & 500 & 500 & 4500 \\
\hline $\begin{array}{l}\text { The second option } \\
\text { total: }\end{array}$ & 27911.145 & 28360.249 & 28095.7818 & 27442.9753 & 8750.4440 & 167297.9231 \\
\hline \multicolumn{7}{|l|}{ including: } \\
\hline $\begin{array}{l}\text { government capital } \\
\text { investment }\end{array}$ & 26911.145 & 27360.249 & 27095.7818 & 26442.9753 & 8250.444 & 160297.9231 \\
\hline other needs & 1000 & 1000 & 1000 & 1000 & 500 & 7000 \\
\hline $\begin{array}{l}\text { The third option } \\
\text { total: }\end{array}$ & 7019.2968 & 7019.2968 & 7019.2968 & 7019.2968 & 5377.8943 & 54943.65 \\
\hline \multicolumn{7}{|l|}{ including: } \\
\hline $\begin{array}{l}\text { government capital } \\
\text { investment }\end{array}$ & 6769.2968 & 6769.2968 & 6769.2968 & 6769.2968 & 5127.8943 & 52693.65 \\
\hline other needs & 250 & 250 & 250 & 250 & 250 & 2250 \\
\hline
\end{tabular}

As we can see, the volume of financing for construction and reconstruction of facilities of Russian penal system is quite impressive. In this regard, it is very important that the funds spent could serve for the benefit of achieving the main goal of penal legislation correction of convicts and prevention of new crimes. One of the means of correcting convicts is the regime. This article is devoted to the influence of violations of construction standards and equipment of correctional institutions in Russia on the organization of the regime of execution of a sentence of imprisonment.

The object of the research is organizational and legal relations arising in connection with the proper design, construction and equipment of correctional institutions of penal system in Russia. The subject is made of regulatory legal acts of Russian Federation (federal laws and departmental regulations of Ministry of Justice of Russian Federation) governing the design, construction and equipment of correctional institutions, as well as the law enforcement practice of correctional institutions of Federal Penitentiary Service of Russia.

The purpose of the article is to structurally analyze the requirements of regulations governing design, construction and equipment of correctional institutions, impact of their violations on the regime of execution of sentences in form of imprisonment.

In this regard, the main tasks of the article are:

- Studying issues of legal regulation of design, construction and equipment of correctional institutions in Russia;

- Studying general requirements for design, construction and equipment of correctional facilities;

- Establishing patterns of influence of violations of design, construction and equipment of correctional institutions on the regime of execution of punishment in form of imprisonment. 


\section{Methods}

The issues of legal regulation of design, construction and equipment of Russian correctional institutions of penal system have not been sufficiently studied. There are only a few works in this area. All of them, in one way or another, are connected with the period when correctional institutions in Russia wanted to be converted from colonies into prisons. Among those, we can single out the work of a team of authors who investigated the issues of internal equipment of correctional institutions as a factor in ensuring law and order at the facilities of penal system (Moscow, 2015); articles by S.Kh. Shamsunov and S.N. Loseva, dedicated to the issues of historical experience of prison construction in foreign countries (Samara, 2018) and N.V. Zubkova, E.G. Pipko, L.L. Chumakov dedicated to the issues of risk assessment of implementation of budgetary projects during the construction of new facilities intended for criminal correctional institutions (Moscow, 2013). Of particular interest are the works of V.V. Bochkarev, who studied the issues of improving the use of engineering and technical means in correctional facilities (Moscow, 2016) and R.Z. Useev who studied the design of penitentiary institutions from the point of view of their fortification (Moscow, 2015). Among recent works, a group of authors should be singled out who investigated the issues of legal regulation of design and construction standards of pre-trial detention centers in Russia (Ryazan, 2020).

In the process of carrying out this research, several general scientific and special scientific methods of cognition were consistently applied. At the initial stage of the study, when assessing the development of Russian legislation on regulation of design, construction and equipment of correctional institutions executing a preventive measure in form of imprisonment, historical and systemic-structural methods of scientific knowledge were used.

At the second stage, in the study of features of regulation of design and construction of correctional institutions in Russia, dialectical method of cognition was used. The same method, along with inductive and deductive methods of formal logic, was used to determine the impact of violations of construction standards and equipment of correctional institutions in Russia on organization of the regime of execution of punishment in form of imprisonment, expediency of changing the provisions of current legislation in the area under study.

\section{Results}

The study showed that in the modern Russian legislation there is no unified approach to the regulation of design, construction and equipment of correctional institutions. Requirements for design, construction and equipment are not concentrated in any single document, they are actually "scattered" according to legal acts of different levels and departments. This situation greatly complicates the process of correct solution of the issues under consideration.

We came to the conclusion that the influence of violations of construction and equipment norms of Russian correctional institutions on the organization of imprisonment regime occurs in several directions: impact on the protection and isolation of convicts; influence on supervision of convicts; influence on execution of duties imposed on convicted persons, realization of their rights and legitimate interests; impact on safety of convicts, staff of correctional institutions and other persons; influence on separation of different categories of convicts; impact on conditions of detention. 


\section{Discussion}

The normative acts governing design, construction and equipment of correctional institutions include:

1. Set of rules. Correctional institutions and centers of penal system. Design Rules / Order of the Ministry of Construction and Housing and Utilities of Russian Federation No. 1454 / pr dated October 20, 2017 (SP 308.1325800.2017);

2. Catalog "Special (security) products for equipment of pre-trial detention centers, prisons, correctional and specialized institutions of Federal Penitentiary Service of Russian Federation / Order of Federal Penitentiary Service of Russian Federation dated July 26, 2007 No. 407;

3. Manual on equipping with engineering and technical means of protection and supervision of objects of penal system / order of the Ministry of Justice of Russia dated September 4, 2006 No. 279;

4. The Criminal Executive Code of Russian Federation in Article 99 (Material and household support for convicts to imprisonment) touches on equipment issues, fixing the norms of living space per one convict in relation to different categories.

In addition, departmental acts cannot regulate general requirements for construction, design, etc. These issues are the prerogative of State Standards, Sanitary and Epidemiological Rules and Regulations, building codes and regulations that must be followed during the construction and equipment of pre-trial detention centers. In particular, for example, federal laws dated December 29, 2004 No. 190-FZ "Urban Planning Code of Russian Federation", dated December 30, 2009 No. 384-FZ "Technical Regulations on the Safety of Buildings and Structures", dated July 22, 2008 No. 123-FZ "Technical regulations on fire safety requirements" and others.

As we can see, the norms for design, construction and equipment of correctional institutions are contained in the documents of different authorities and in documents of different levels of legal force.

Let's proceed directly to the consideration of legal regulation of the object of our research. The territory of a correctional institution in Russia, as a rule, consists of a protected and non-protected area. The protected area is divided into a residential area and an industrial area.

The residential area is an isolated area with residential, cultural, utility, communal and special buildings where convicts live. The residential area accommodates: hostels for convicts detachments, a quarantine room for convicts who have arrived at the institution, a school, a canteen, a shop, classrooms for vocational training, a club, a library, a medical unit, a hairdresser, a gym, a room for telephone calls, offices of some services administration and a number of other premises. On the territory of the residential area of the colony, local areas are equipped: with normal conditions, facilitated, strict conditions for serving a sentence, as well as a separate building of a punishment cell, cell-type rooms and single cell-type rooms designed to isolate violators of the sentence serving regime. Sports grounds are being set up on the territory of local sections of the colony. In the fences of local areas, swing gates and wickets are arranged, equipped with electromechanical locking devices. Compliance with these requirements is of great importance and, in particular, for the installation of grilles, certain types of doors and locks in one place or another.

The production area is an isolated area where various production facilities are located where convicts work.

The territories of residential and production areas are divided into isolated local areas intended to isolate groups of convicts from each other. Each of them should have no more than 250-300 people. They are fenced with fences made of metal meshes with a height of 3 
$\mathrm{m}$. If it is impossible to make such sections in the production area due to the peculiarities of the technological process, then an interdepartmental access control is organized.

Residential, utility, production buildings, other buildings are located no closer than 15 $\mathrm{m}$ to the external fence of the institution. Building windows facing the external fence are equipped with metal bars, if necessary, and the glass is painted. The external fencing of correctional facilities is a complex, multi-stage system. Due to the limited scope of this article, we will not dwell in detail on the structure of external fence.

The living area and the production area, as well as the cell-type premises and the punishment cell are separated from other buildings by visible corridors. This is a fenced-in strip of terrain separating adjacent isolated areas of the colony. It is equipped with two parallel fences spaced 7-9 $\mathrm{m}$ apart and $3 \mathrm{~m}$ high.

At the junction of adjacent residential and production areas, as a rule, there are premises for employees who control the behavior of convicts. An internal checkpoint with premises for conducting searches is also equipped here.

In all special buildings located in the residential and production areas, the walls facing the external fence are built with capital, at least $38 \mathrm{~cm}$ thick, reinforced with a metal grill and blocked by a burglar alarm.

Outside the protected zone of the colony, there are: an administrative building, various kinds of warehouses, a bakery, garages, a pharmacy, hostels for prisoners who use the right to move without an escort, a hotel, premises for studying and changing clothes for employees of the duty service, a gym for employees.

Equipping buildings and premises located on the territory of correctional institutions is of no small importance for the proper maintenance of the regime. First of all, these are: doors with locks; window bars; lattice partitions.

All entrances to special buildings (premises) are equipped with reinforced doors with locks. If necessary, they are also equipped with optical peepholes or other devices for visual monitoring of situation in front of the door. Doors are divided into reinforced doors and latticed doors. In turn, the locks used on such doors can be both mechanical and electromechanical, when electrical energy is required to operate them.

Window bars. Despite the apparent simplicity of these pieces of equipment for correctional facilities, they play an equally important role in ensuring the regime than fences or doors. They are chambered for installation in chambers. Special, for installation of windows in houses and public buildings. Decorative, serving, among other things, for solving problems of aesthetics.

Lattice partitions are the next element of equipment of restricted areas of correctional institutions. Three types of lattice partitions can be distinguished: longitudinal, installed in corridors and underground passages, as well as in corridors of regime buildings with twosided arrangement of chamber rooms; transverse, installed at the ends of the blocks of cell rooms, at the ends of transitional galleries, at the entrances to the stairwells of secure buildings and in the corridors of checkpoints; cut-off, installed to block access to the windows from the side of the cell rooms.

\section{Conclusion}

Summing up, we came to following conclusions:

1) In Russia, there is a multi-level regulatory subordination in solving the problems of design, construction and equipment of correctional institutions. On the one hand, there are norms of the Ministry of Justice and the Federal Penitentiary Service, on the other - the Ministry of Construction and Housing and Communal Services. Such a situation does not help to quickly and qualitatively solve the problems, eliminate shortcomings, and achieve the goals. 
2) Based on the results of the study, we propose to create a unified legal document regulating the procedure for design, construction and equipment of correctional institutions. Such a document should be developed jointly by the Ministry of Justice and the Ministry of Construction, Housing and Utilities. This will provide a proper, common understanding of existing problems and a more universal and faster solution.

3) The impact of violations of construction standards and equipment of correctional institutions in Russia on the organization of the regime of execution of punishment in form of imprisonment is negative in several ways. They can be classified as follows:

1. Impact on the protection and isolation of convicts:

- non-observance of established distances when equipping exclusion zones;

- incorrect design of sewerage, drains and heating mains;

- violations of requirements for equipping the perimeter, boundaries of zones with warning and information signs.

2. Impact on the supervision of convicts:

- non-observance of requirements for installation of grilles, types of doors and locks;

- incorrect placement of equipment elements, as a result of which so-called "blind spots" are formed, inaccessible for constant monitoring by employees of institutions;

- violation of the norms of minimum area for one convict.

3. Impact on the execution of duties assigned to the convicted, realization of their rights and legitimate interests:

- violation of sanitary and epidemiological norms, including the norms of minimum area for one convict.

4. Impact on the safety of convicts, staff of correctional institutions and other persons:

- non-observance of established standards for placement of window and cutoff grilles, types of doors and locks, key catchers;

- incorrect placement of equipment elements, as a result of which so-called "blind spots" are formed, inaccessible for constant monitoring by employees of institutions;

- violation of sanitary and epidemiological standards.

5. Impact on the separation of different categories of convicts:

- non-observance of the norms of minimum area for one convict;

- violation of requirements for installation of grilles, types of doors and locks.

\section{References}

1. I.V. Karavaev, A.N. Kimachev, V.V. Prokudin, S.N. Suharev, S.N. Matulis, E3S Web of Conferences 217, 010112020 (2020)

2. V.V. Bochkarev, Actual problems of Russian law 4(65), 168-175 (2016)

3. N.V. Zubkova, E.G. Pipko, L.L. Chumakov, Economics: realities of time 4.4(9), 101105 (2013)

4. L.O. Pichugina, T.V. Zalatina, A.I. Gatina, Scientific Almanac 11-3(13), 351-355 (2015)

5. R.Z. Useev, Bulletin of penal system 10(161), 19-22 (2015)

6. V.V. Fedorov, A.N. Sapozhnikov, L.F. Pertli, Yu.Yu. Zheleznaya, V.S. Kokhtachev, M.A. Kaluzhina, O.A. Ibragimov, Internal equipment of correctional institutions as a factor in ensuring law and order at the facilities of penal system. Analytical review of work experience (Moscow, 2015)

7. S.Kh. Shamsunov, S.N. Loseva, Bulletin of Samara Law Institute 3(29), 93-97 (2018)

8. V.F. Lapshin, S.A. Korneev, E3S Web of Conferences 135, 04063 (2019) DOI: 10.1051 / e3sconf / 201913504063 
9. A.A. Brovkina, V.E. Vezlomtsev, S.S. Zakharova, O.A. Shuranova, Yu.V. Truntsevsky, E3S Web of Conferences 135, 04066 (2019) DOI: 10.1051 / e3sconf / 201913504066

10. V. Lez'Er, N. Semerianova, A. Kopytova, Y. Truntsevsky, E3S Web of Conferences 110, 02093 (2019) DOI: 10.1051/e3sconf/201911002093

11. A.V. Kopytova, N.S. Zotkina, I.G. Reshetnikova, MATEC Web of Conferences 239, 04012 (2018) DOI: 10.1051/matecconf/201823904012

12. V. Lez'Er, N. Semeryanova, A. Kopytova, I. Kvach, E3S Web of Conferences 110, 02094 (2019) DOI: 10.1051/e3sconf/201911002094

13. R. Kolobov, U. Filatova, V. Borshcheniuk, N. Semerianova, D. Bayanov, E3S Web of Conferences 110, 02095 (2019) DOI: 10.1051/e3sconf/201911002095

14. Y.V. Truntsevsky, I.I. Lukiny, A.V. Sumachev, A.V. Kopytova, MATEC Web of Conferences 170, 01067 (2018) DOI: 10.1051/matecconf/201817001067 